
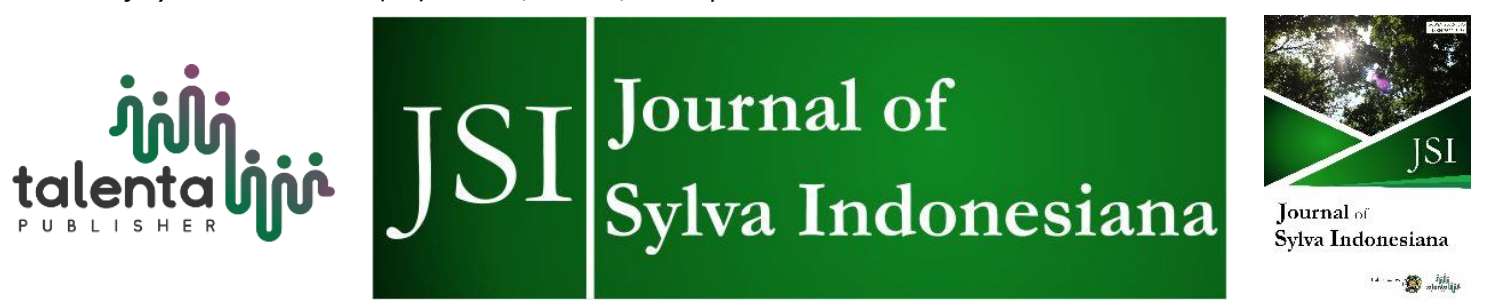

\title{
Analysis of Regional Regulation Number year 2015 Implementation on Urban Green Space Management in Mataram City
}

\author{
Lale Dini Ardiantari ${ }^{1}$, Andi Chairil Ichsan ${ }^{1 *}$, and Kornelia Webliana ${ }^{1}$ \\ ${ }^{1}$ Major of Forestry, Faculty of Agriculture, Universitas Mataram, West Nusa Tenggara, Indonesia
}

\begin{abstract}
Green open space is an area that has a function as well as a place to grow plants, both those that grow naturally and are planted. One way to improve environmental quality and revitalize urban ecosystems is by managing the Green Open Space. One of the alternatives supporting this effort is to make supportive and applicable policies, laws, and regulations. This research was conducted to examine the implementation of Regional Regulation Number 8 of 2015 regarding Green Open Space Management in Mataram City and to find out planning strategies in optimizing the implementation of applicable policies. The method used in this research is literature study method, interview, and observation. In this study, six criteria are used based on William N. Dunn's theory to analyze policies and SWOT analysis to determine the appropriate management strategy. The policy implementation analysis results show that the implementation of these regional regulations falls into the "medium" category with a score of 2.13. This indicates that several indicators need to be tightened to optimize policies' effectiveness, so it is necessary to revise policies to maximize implementation. Several strategies that can be carried out to maximize the role of stakeholders are disseminating information about the content of local regulations that are applied to all related parties, explaining the programs that will be implemented to create a common understanding for all parties as a whole based on the objectives to be achieved, optimizing local regulations which applies to improve coordination in the implementation of green open space management which aims to maximize the role between agencies to create adequate technical personnel, facilities and infrastructure and synchronize the main tasks and functions of each agency in implementing green open space management to maximize their respective roles.
\end{abstract}

Keyword: Analysis, Implementation, Green Open Space, Optimization

Received 27 January 2021 | Revised 30 January 2021 | Accepted 17 February 2021

\section{Introduction}

The increase in population resulted in increased land requirements for settlement. This condition also has an impact on land conversion and causes less open land that can be used by the community. The city's current dense population has resulted in the formation of slum settlements that affect the environment's quality. Decreasing environmental quality causes

\footnotetext{
*Corresponding author at: Major of Forestry, Faculty of Agriculture, Universitas Mataram, Jl. Majapahit No 62, Mataram, West Nusa Tenggara, Indonesia
}

E-mail address: andi.foresta@unram.ac.id 
several disturbances such as floods, air pollution, noise, etc., reducing people's productivity. One of the important components that must be owned by urban areas is Green Open Space. According to Law Number, 26 the Year 2007 Green Open Space is a longitudinal area/pathway or group, which is used more openly, a place to grow plants, both those that grow naturally and those that are intentionally planted. Green Open Space, commonly called RTH, has several functions: ecological, economic, socio-cultural, and aesthetic.

Mataram, located in West Nusa Tenggara, has an area of $61.30 \mathrm{~km}^{2}$. In 2017, the total population of Mataram City reached 419,506 people with a density of around 6,843 people $/ \mathrm{km}^{2}$. Based on the prevailing policy, the proportion of green open space that must be owned in each city area is at least $30 \%$ of the city's total area, which is then divided into $20 \%$ public green open space area and $10 \%$ for private green open space area. The city of Mataram must have at least $18,390,000 \mathrm{~m}^{2}$ of green open space consisting of $12,260,000 \mathrm{~m}^{2}$ of public green open space and $6,130,000 \mathrm{~m}^{2}$ of private green open space.

Green open space management can be the right alternative to improve environmental quality and revitalize urban ecosystems. Establishing applicable and efficient policies and laws and regulations can support the success of this effort. Therefore, a study on the policies implementation regarding the Management of Green Open Space in Mataram City, using Regional Regulation Number 8 of 2015 , needs to be carried out. This study aims to examine the implementation of the policy of Regional Regulation Number 8 of 2015 concerning Green Open Space Management in Mataram City and to determine the planning strategy in optimizing the implementation of the applicable policies.

\section{Method}

This research was conducted in the Mataram City green open space (GOS). The data and document collection of Regional Regulation Number 8 of 2015 was carried out as the research object. Respondents were selected based on their relationship with green open space managers, namely people living around green open space and stakeholders living in public works housing and government agencies in charge of managing green open space. The data collected in this study are primary and secondary data. The secondary data collected by literature studies based on research variables and primary data is obtained from interviews and observations.

The data analysis used in this research is qualitative and quantitative. Qualitative data analysis is an analysis carried out by describing the research location, determining the planning strategy in policy optimization, and the results of policy evaluation analyzed using the content analysis method. Content analysis is a technique used to describe the conclusions through an effort to find the characteristics and is carried out objectively and systematically [1]. The categories used in the content analysis method in this study follow Willian Duun (2003) theory. Quantitative data analysis is an analysis carried out on the Likert scale data based on the criteria developed 
by William Dunn in [2], which focuses on six criteria and weighting results analysis, which is carried out using SWOT analysis.

The evaluation of policy performance used in this study is a Likert scale model Sugiyono (2018) in [3] with a range of 1 to 3 :

1: Not Achieved/Less Clear/Bad/Disagree /Not Exactly

2: Sufficiently accomplished/Sufficiently clear /Good Enough /Uncertain /Sufficiently Relevant 3: Achieved/Clear/Good/Agree/Precise

The analysis results are presented in a formulation using an index. The index can be calculated using the mean formula, which is to calculate the total value of all indicators then divided by the number of indicators in each variable. The policy assessment index is categorized into three classes, namely: High, Medium, and Low.

Table 1 Category of Index Value

\begin{tabular}{lll}
\hline Rating Index & Category & \multicolumn{1}{c}{ Description } \\
\hline $2.34-3.00$ & High & $\begin{array}{l}\text { Is the ideal average value obtained from each quality } \\
\text { element, indicator, and criteria. }\end{array}$ \\
$1.67-2.33$ & Medium & $\begin{array}{l}\text { Is the medium category average value obtained from } \\
\text { each quality element, indicator, and criteria. }\end{array}$ \\
$1.00-1.66$ & Low & $\begin{array}{l}\text { Is a low average value obtained from each quality } \\
\text { element, indicator, or criteria. }\end{array}$ \\
\hline
\end{tabular}

SWOT analysis is a systematic identification of various factors to formulate a company strategy. This analysis is based on logic that maximizes strengths and opportunities but simultaneously minimizes weaknesses and threats. The strategic decision-making process is always related to the developing the company's mission, goals, strategies and policies [4].

Table 2 Matrix of SWOT Analysis

\begin{tabular}{lll}
\hline $\begin{array}{l}\text { Internal factors/ } \\
\text { External factors }\end{array}$ & \multicolumn{1}{c}{ Strengths } & \multicolumn{1}{c}{ Weaknesses } \\
\hline Opportunities & $\begin{array}{l}\text { Strength-Opportunity strategy } \\
\text { (SO) }\end{array}$ & $\begin{array}{l}\text { The Weakness-Opportunity } \\
\text { strategy (WO) }\end{array}$ \\
Threats & $\begin{array}{l}\text { The Strength-Threat strategy } \\
\text { (ST) }\end{array}$ & $\begin{array}{l}\text { The Weakness-Threat } \\
\text { strategy (WT) }\end{array}$ \\
\hline
\end{tabular}

\section{Results and Discussion}

\subsection{General description of the research location}

Mataram is the capital city of West Nusa Tenggara Province, located on Lombok Island. Geographically, Mataram city is situated on the western end of Lombok Island, which is between West Lombok Regency and the Lombok Strait. Mataram is located at the position of $08^{\circ} 33^{\prime}-08^{\circ} 38^{\prime}$ Slatitude and between $116^{\circ} 04^{\prime}-116^{\circ} 10^{\prime} \mathrm{E}$, with the boundaries as follows: 
- In the north it is bordered by Gunungsari District, Batulayar District and Lingsar District.

- In the west bordering the Lombok Strait.

- In the east it is bordered by Narmada and Lingsar District.

- In the south it is bordered by Labuapi District.

Topographically, the Mataram city is lowland and medium while the the northern part, is mountainous and hilly land. Mataram city is located at an altitude of 50 meters above sea level (m.asl), so most of its area is flat land. Based on the Mataram I Climatology station data, the average air temperature in Mataram ranges from $22.7{ }^{\circ} \mathrm{C}$ to $32{ }^{\circ} \mathrm{C}$ in 2018 . The average air humidity in this city varies considerably $77 \%$ to $86 \%$. The highest rainfall was recorded in January at $449 \mathrm{~mm}$, and the highest rainy day was recorded in January at 30 days.

Administratively, Mataram city has an area of $61.30 \mathrm{~km}^{2}$, which is divided into six districts, namely Ampenan, Sekarbela, Mataram, Selaparang, Cakranegara, and Sandubaya Districts. The largest sub-district is the Selaparang with an area of $10.77 \mathrm{~km}^{2}$, followed by the Mataram subdistrict with an area of $10.76 \mathrm{~km}^{2}$. The smallest is Ampenan District, with an area of $9.46 \mathrm{~km}^{2}$.

\subsection{Policy Profile: Regional Regulation Number 8 of 2015}

Mataram City Regional Regulation Number 8 of 2015 deals with managing green open spaces in Mataram City, consisting of 13 chapters and 34 sections. In detail, the contents of the regional regulation are as follows:

1. General Provisions (Article 1)

2. Objectives, Functions and Benefits (Articles 2, 3, and 4)

3. Green Open Space Management (Articles 5-9)

4. Implementation of Green Open Space Management (Articles 10-19)

5. Community Participation (Articles 20, 21 and 22)

6. Development, Supervision, Control and discipline (Articles 23 and 24)

7. Funding (Article 25)

8. Prohibition (Article 26)

9. Administrative Sanctions (Articles 27, 28 and 29)

10. Investigation (Article 30)

11. Criminal Provisions (Article 31)

12. Transitional Provisions (Article 32)

13. Closing Provisions (Articles 33 and 34)

Regional regulations on GOS Management were formed based on several considerations, those were the development of area which is a tendency for the community to divert green open space areas for various purposes with other functions, in the framework of realizing an environmental development and improving the quality of life for present and future generations, local 
government policies are needed regarding planning, utilization, control, and green open spaces and the last, the responsibility for environmental preservation is a shared responsibility between the regional government and the community. Based on these considerations, it is very important to establish a Regional Regulation on GOS Management.

\subsection{Analysis of the Implementation of Regional Regulation Number 8 year 2015}

The analysis of regional regulation number 8 of 2015 implementation was carried out using six criteria, namely effectiveness, efficiency, adequacy, leveling, responsiveness, and accuracy. If the average criteria score is accumulated, then a score of 2.13 will be obtained, which falls into the medium category. Details of the variation in the value of each criterion are presented in Figure 1.

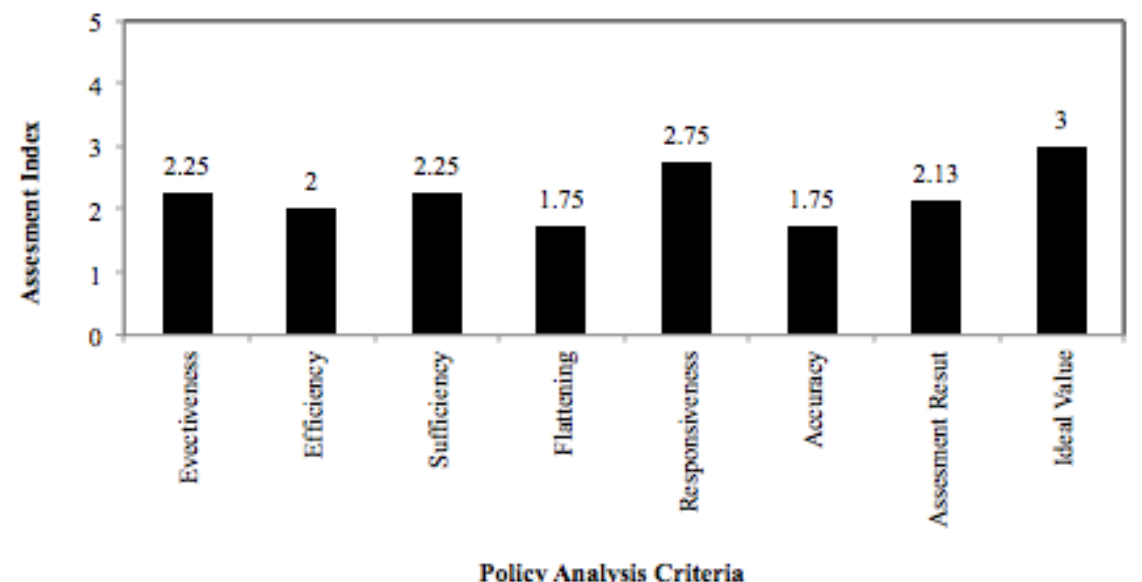

Figure 1 Result of Analysis Implementation

The diagram above shows that of the six criteria used in measuring the performance of regional regulation Number 8 of 2015, starting from effectiveness, efficiency, sufficiency, flattening, and accuracy, all are in the moderate category. Each criterias are explained in several points as follows:

\section{A. Effectiveness}

Effectiveness relates to the extent to which the goals can be achieved. Based on the research results, the average value of the effectiveness criteria assessment results is 2.25 and classified into the medium category with a value range of 1.67 to 2.33 . Several things must be done, including meeting the target area of green open space of $30 \%$ to maintain land availability as water catchment areas. However, based on the results of interviews obtained by researchers, the total area of green open space that has been achieved by the Mataram City Government has only reached $27.18 \%$. This amount is still below the minimum target that has been set at $30 \%$. Based on interviews result, it is known that this is due to the high rate of land conversion due to the rapid development of the city. Apart from urban development, the construction of housing is also one of the reasons for land conversion. 
For private green open space, the Mataram City government has succeeded in building an area of 881.44 hectares or $14.38 \%$ of the total area of Mataram City (SLH Mataram 2019). This indicated that the area of private green open space was appropriate and even exceeded the minimum target area set at $10 \%$. Based on the interview results, one example of private green open space in the city of Mataram is the Mataram University urban forest area.

As for public green open space, the government of Mataram City has just managed to build a green open space of 765.07 ha or $12.48 \%$ of the city's total area. Meanwhile, the minimum area of public green open space that Mataram City must fulfill based on the provisions is $20 \%$ of the total area of the city of Mataram or equivalent to 1,226 hectares, so it is necessary to add $7.52 \%$ or 460.93 hectares of public green open space. Several public green open spaces in Mataram City are Sangkareang Park, Ampenan Beach Park, Selagalas Park, and so on (SLH Mataram 2019).

The lack of available data related to the policy implementation report that has been carried out prevents researchers from conducting further tests related to the truth in the field. Less than optimal implementation can result in a reduction in the area of green open space. Meanwhile, the increasing population will have a negative impact on the target of providing a healthy, clean, beautiful, and comfortable environment. According to [5], economic growth and population centered in urban areas demand a wider space outside the city for various economic activities and settlements. The impact that arises is the reduction in urban green open space. The decreasing quantity of green open space accompanied by low quality causes the balance of the city environment's ecological carrying capacity to be not maintained.

\section{B. Efficiency}

Based on the interview result and field observations that have been carried out, the average value of the efficiency criteria is 2 , which is included in the moderate category. This is because some of the mandates of regional regulations do not significantly influence before and after the enactment of these regional regulations.

For example, as stated in section 5 clauses 2 concerning the provision of an ideal green open space area of at least $30 \%$ of the total urban area, it has not yet reached the minimum target. In addition, in section 11 paragraphs $\mathrm{a}, \mathrm{b}, \mathrm{c}, \mathrm{d}$, and e, the minimum area of green open space that the government must provide based on the population is still not realized. The analysis of the minimum target's achievement, which is the policy's impact in increasing public awareness and decreasing the violation index, shows a value of 2.25 , which is included in the medium category.

Section 22 clause 1 (a) of Regional Regulation number 8 the year 2015 states that community members can participate through the provision of RTH in the yard/yard of their respective homes, but the community has not maximally implemented the implementation of this section. 
Lack of socialization carried out regarding the importance of green open space for urban community life and lack of information to the public and related parties about the importance of the role of green open space as a comfortable area for activities and as a support for the living environment is one of the triggers for the lack of public awareness. In fact, community involvement in providing GOS is very much needed. Given the importance of GOS as a place for social interaction and economic activities, which can improve community development, this will impact productivity and improve the quality of life of the community [6].

There has been no government program to raise awareness of the importance of green open space. So local governments need to start socializing the importance of green open spaces to foster a sense of concern for the environment to increase public awareness. In addition, conveying to the public about the importance of protecting the environment, which is done together with a strong synergy between the government and the community, is very important.

\section{C. $\quad$ Flattening}

On the criteria for flattening, the main focus of evaluation is on the roles and responsibilities in carrying out the policy mandate and how evenly green open spaces have been built in each region in Mataram City. The evaluation results show that the leveling criteria are in the medium category with a score of 1.75 out of 3 . Currently, there is no clear written division of roles among the related agencies during policy implementation. So that between agencies and another do not understand the limitations of the role they have. To achieve a public or private organization's success in achieving a goal, a division of labor is required, which is an absolute necessity, without which the possibility of overlapping will be even greater. In carrying out work activities, it is necessary to have a division of labor to create order and clarity of work towards achieving goals to improve the quality of service to the community [7].

Strong coordination is needed between one agency and another in implementing green open space management to be carried out optimally. So it is necessary to have a discussion forum between related agencies to discuss and clarify the duties and functions of each agency with the hope of forming strong teamwork in the implementation of management. However, based on the development of green open space in all parties, it is considered almost evenly distributed. Almost in every view of all parties, there is a public green open space used by the surrounding community.

\section{Responsiveness}

Responsiveness relates to how far the results of a policy can satisfy the community. Based on the analysis results, the average responsiveness criterion has a score of 2.75 from the ideal value of 3. The assessment index from the value of 2.34 to 3.00 falls into the high category. This shows that the performance carried out by the government has satisfied the community. This can be proven by the existence of new green open space construction locations and how the green open space's existence affects them. 
Green open space has many functions, including ecological, socio-cultural, architectural, and economic functions. In terms of socio-culture, green open space can function as a space for social interaction, a means of recreation, and a city's cultural centerpiece [8]. This can be seen directly by community activities around the monument area, either for taking photos or sitting casually with relatives. In addition, architecturally, green open space can increase the value of the city's beauty and comfort.

\section{E. Accuracy}

The evaluation results show that the accuracy criteria fall into the medium category in the conformity perspective with a score of 1.75 . The results of policy analysis based on six criteria are depicted in a diagram, which shows that the value obtained belongs to the moderate category (Figure 2). This indicates that the policy has not been maximally implemented to achieve its goals. It is suspected that this happens because there are still internal and external problems that hinder goal achievement. Some issues can be seen as a tangible form of obstacles to achieving goals, namely the lack of awareness and participation of the community in managing green open space, the need for land, increasing population growth, and so on.

In addition, the values stated in the regional regulations are still not explained in detail. As in article 23, paragraph 3, it relates to the members of the supervision and control team that have been determined, consisting of the Gardening Service, the City Planning Service, the Public Works Service, the Cleaning Service, to the smallest sections such as the local Camat and Lurah. In this case, there is no explanation related to the scope of duties and functions that will be carried out by each member. Article 27, which contains the sanctions, is not detailed. An explanation regarding the sanctions imposed on parties who do not meet the requirements for fulfilling the green open space based on the valid development permit is not clearly stated. This impacts the lack of concern and sense of responsibility for the community and related parties in participating in building and maintaining green open spaces. Based on this, it is very important to implement sanctions that can have a deterrent effect. One form of sanction can be issuing a warning letter to the imposition of fines.

The implementation and explanation in detail related to the content and firm and clear sanctions against the implementers and managers of green open spaces in Regional Regulation Number 8 of 2015 have not been maximized. There are still many shortcomings. Therefore, it is necessary to revise the contents of the policy to strengthen the policy's performance. It is also required to impose sanctions on government agencies that are not strict in carrying out their obligations and duties to manage green open spaces to encourage the government to carry out its role to the fullest.

\subsection{Green open space management plan strategy}

The SWOT matrix is the final stage carried out after determining the factors that are strengths, weaknesses, opportunities, and threats. The SWOT matrix is a tool used to formulate strategic 
factors. This matrix can clearly describe how opportunities and threats the company faces to adjust to its strengths and weaknesses. The results of determining the SWOT matrix in the management of green open spaces in the City of Mataram are presented in the following table:

Table 3 SWOT Matrix of the Planning Strategy for RTH Management

\begin{tabular}{|c|c|c|}
\hline & Strength (S) & Weakness (W) \\
\hline Internal / External & $\begin{array}{l}\text { 1. Availability of an } \\
\text { adequate budget } \\
\text { 2. Availability of } \\
\text { experienced human } \\
\text { resources } \\
\text { 3. The availability of main } \\
\text { duties and functions in } \\
\text { the housing and } \\
\text { residential area offices }\end{array}$ & $\begin{array}{l}\text { 1. Coordination between } \\
\text { fields is not yet steady } \\
\text { 2. inadequate facilities and } \\
\text { infrastructure for } \\
\text { managing green open } \\
\text { spaces } \\
\text { 3. The lack of local } \\
\text { government capacity in } \\
\text { implementing } \\
\text { government } \\
\text { commitments to provide } \\
\text { green open spaces }\end{array}$ \\
\hline $\begin{array}{l}\text { Oppurtunity }(\mathrm{O}) \\
\text { 1. There is third party } \\
\text { assistance } \\
\text { 2. There is support for } \\
\text { local regulations, } \\
\text { operational guidelines } \\
\text { and technical } \\
\text { guidelines } \\
\text { 3. The existence of } \\
\text { information and } \\
\text { communication links } \\
\text { between agencies }\end{array}$ & $\begin{array}{l}\text { Optimizing local } \\
\text { regulations that support the } \\
\text { design and implementation } \\
\text { of the operational and } \\
\text { technical guidelines to the } \\
\text { maximum and utilize the } \\
\text { budget according to the } \\
\text { plan that has been prepared } \\
\text { to maximize the } \\
\text { implementation of green } \\
\text { open space management. } \\
\mathrm{S} 1+\mathrm{O} 2=1,54+1,41= \\
2,95\end{array}$ & $\begin{array}{l}\text { Optimizing applicable } \\
\text { regional regulations to } \\
\text { improve good coordination } \\
\text { in the implementation of } \\
\text { green open space } \\
\text { management in order to } \\
\text { maximize the role between } \\
\text { agencies so as to create } \\
\text { adequate technical } \\
\text { personnel, facilities and } \\
\text { infrastructure. } \\
\mathrm{W} 1+\mathrm{O} 2=0,88+1,41= \\
2.29\end{array}$ \\
\hline $\begin{array}{l}\text { 1. Unifying perceptions } \\
\text { with third parties } \\
\text { 2. Public awareness is } \\
\text { still lacking } \\
\text { 3. High land use change } \\
\text { and high demand for } \\
\text { tree cutting }\end{array}$ & $\begin{array}{l}\text { Conducting outreach } \\
\text { regarding the contents of } \\
\text { regional regulations that } \\
\text { apply to all parties } \\
\text { concerned and explaining } \\
\text { the programs that will be } \\
\text { implemented to create the } \\
\text { same understanding to all } \\
\text { parties simultaneously } \\
\text { based on the objectives to } \\
\text { be achieved. } \\
\mathrm{S} 1+\mathrm{T} 1=1,54+0,80= \\
2,34\end{array}$ & $\begin{array}{l}\text { Synchronizing each } \\
\text { agency's main tasks and } \\
\text { functions of each agency in } \\
\text { implementing green open } \\
\text { space management to } \\
\text { maximize their respective } \\
\text { roles. } \\
\mathrm{W} 1+\mathrm{T} 2=0,88+0,80= \\
1,68\end{array}$ \\
\hline
\end{tabular}

Source: Primary Data 2020

Based on table 3, it can be seen that the highest value of the swot matrix is the S-O strategy, which is 2.95 . The S-O strategy is a strategy that is carried out by utilizing all the strengths that are owned to get and take advantage of the greatest opportunities. The S-O strategy is one of the strategies used by utilizing all existing strengths to be able to take advantage of all the opportunities that are owned [9]. Strategies that can be used to improve the management of 
green open space in the city of Mataram are optimizing supporting regional regulations to design and implement operational and technical guidelines to the maximum and utilize the budget according to the plan that has been prepared to maximize the implementation of green open space management.

In addition, for the strategy that is in the second place is the S-T strategy, which is a strategy that is carried out by using the strength they have to overcome any threats that may arise. This strategy has a value of 2.34. The S-T strategy is a strategy for dealing with and overcoming threats by utilizing their strength [10]. According to [11], companies try to avoid or reduce the impact of external threats through this strategy. The strategy that can be done is to carry out socialization related to the contents of regional regulations that apply to all related parties and explain the programs that will be implemented to create the same understanding to all parties simultaneously based on the objectives.

Meanwhile, the strategy that is in the third place is the W-O strategy with a value of 2.29. The W-O strategy is one of the strategies that you have to minimize your weaknesses to take advantage of all the opportunities that exist [12]. This strategy is a strategy to take advantage of existing opportunities by minimizing the weaknesses they have. This strategy can be implemented by optimizing the applicable regional regulations to improve good coordination in the implementation of green open space management to maximize the role between agencies to create adequate technical personnel, facilities, and infrastructure.

The strategy with the lowest score is the $\mathrm{W}-\mathrm{T}$ strategy with a value of 1.68 . The $\mathrm{W}-\mathrm{T}$ strategy is a strategy carried out by minimizing existing weaknesses and avoiding threats. When viewed based on the activities carried out, the W-T strategy is a defensive strategy. This strategy is carried out to minimize weaknesses and threats [13]. In this case, the strategy used is synchronizing the main tasks and functions of each agency in the implementation of green open space management to maximize their respective roles.

\section{Conclussion}

Based on the analysis results on the six policy evaluation criteria, it can be concluded that Regional Regulation Number 8 of 2015 concerning Green Open Space Management in Mataram City has not run optimally with the value obtained of 2.13 , which is in the moderate category. There are several matters contained in the Perda that still need to be strengthened to optimize policy. Therefore, changes or revisions to strengthen the performance of these policies need to be made.

Strategies that can be used to optimize the implementation of green open space management in the City of Mataram are: Conducting socialization regarding the contents of regional regulations that apply to all related parties and explaining programs to be implemented to create the same 
understanding to all parties simultaneously based on the objectives to be achieved; Optimizing the applicable regional regulations to improve good coordination in the implementation of green open space management in order to maximize the role between agencies so as to create adequate technical personnel, facilities and infrastructure; Synchronizing the main tasks and functions of each agency in implementing green open space management to maximize their respective roles.

\section{REFERENCES}

[1] Satori, Djam'an, and Komariah, A., Metodologi Penelitian Kualitatif. Alfabet, Bandung, 2009.

[2] Ichsan, A. C., Aji, I. M. L., Webliana, K., and Sari, D. P., "The Analysis of Institutional Performance of The Village Conservation Model in Gunung Rinjani National Park," In IOP Conference Series: Earth and Environmental Science, IOP Publishing, vol. 270, no. 1, p. 012019. 2019.

[3] Ichsan, A. C., Aji, I. M. L., Anwar, H., Waru, T., and Febryano, I. G. "The implementation of conservation village modelprogram in mount Rinjani National Park (A Regulation Perspective)," Ecology, Environment, and Conservation, vol. 26, no. 3, pp. 1100-1109. 2020.

[4] Rangkuti, and Freddy. Analisis SWOT: Teknik Membedah Kasus Bisnis. Gramedia Pustaka Utama, Jakarta, 2015.

[5] Nugroho, I., and Dahuri, R. Pembangunan Wilayah. LP3ES, Jakarta, 2004.

[6] Maulan, A.F.R., and Sulistyarso, H. "Strategi Optimalisasi Ruang Terbuka Hijau Publik Berdasarkan Preferensi Masyarakat di Kecamatan Jambangan, Surabaya," Jurnal Teknik ITS, vol. 8, no. 2, pp. 130-135. 2019.

[7] Azhari, A.R., and Wahid, A.A. "Pengaruh Pembagian Kerja Terhadap Kualitas Pelayanan di Desa Pamekarsari Kecamatan Banyuresmi Kabupaten Garut," Jurnal Pembangunan dan Kebijakan Publik, vol. 7, no. 2, pp. 29-38. 2016.

[8] Dwiyanto, A. "Kuantitas dan Kualitas Ruang Terbuka Hijau di Permukiman Perkotaan," Jurnal Teknik, vol. 30, no. 2, pp. 88-93. 2009.

[9] Kartila, N. "Kontribusi Hasil Hutan Bukan Kayu Kemiri (Aleurites moluccana (L) Willd.) terhadap Pendapatan Petani Hutan Kemasyarakatan Tangga di Desa Selengen Kecamatan Kayangan Kabupaten Lombok Utara," Undergraduated Thesis, Universitas Mataram, 2018.

[10] Nurhayati, S. "Analisis Strategi Sistem Teknologi Informasi dengan Pendekatan Analisis SWOT (Studi Khusus Defisi IT Rumah Sakit Mata Cicendo Bandung)." Jurnal Seminar Nasional Informatika, vol. 1, no. 5. 2015.

[11] Ramadhan, A., and Sofiyah, F.R. "Analisis SWOT Sebagai Landasan Dalam Menentukan Strategi Pemesaran (Studi Kasus McDonald'S Ring Road)," Jurnal Media Informasi Manajemen, vol. 1, no. 4. 2013.

[12] Mariyam, S. "Pendekatan SWOT dalam Pengembangan Objek Wisata Kampoeng Djowo Sekatul Kabupaten Kendal," Undergraduated Thesis, Universitas Deponogoro, 2011.

[13] Tamara, A. "Implementasi Analisis SWOT Dalam Strategi Pemasaran Produk Mandiri Tabungan Bisnis,” Jurnal: Riset Bisnis Dan Manajemen, vol. 4 no. 3. 2016. 